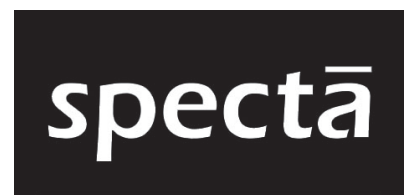

Journal of Photography, Arts, and Media

Volume 2 Nomor 2,

\section{FOTOGRAFI SEBAGAI MEDIA MONITORING URBAN FARMING BERBASIS PENDOKUMENTASIAN DAN PARTISIPASI ANAK DALAM MENCIPTAKAN LINGKUNGAN RAMAH ANAK DI WILAYAH PEGIRIAN SURABAYA}

Idealita Ismanto

Pendidikan Seni dan Budaya

Pascasarjana Universitas Negeri Surabaya

Surel: idealita.dea@gmail.com

\begin{abstract}
Abstrak
Penelitian ini membahas permasalahan tentang monitoring urban farming yang dilakukan oleh anak dengan menggunakan media pembelajaran fotografi sebagai pendokumentasian lingkungan tempat tinggal anak di wilayah pegirian Surabaya. Persoalan yang diangkat membahas bagaimana peran media fotografi digunakan sebagai monitoring urban farming di wilayah pegirian Surabaya serta dampak monitoring keluarga dan anak dengan partisipasi anak dalam menciptakan lingkungan ramah anak di wilayah pegirian Surabaya. Metode yang digunakan yakni observasi dan wawancara. Kegiatan analisis data dimulai dari tahap pengumpulan data, tahap reduksi, tahap penyajian data, serta tahap penarikan kesimpulan dengan penelitian kualitatif. Dapat disimpulkan bahwa hasil dari monitoring urban farming berbasis pendokumentasian dan partisipasi anak dalam menciptakan lingkungan ramah anak di wilayah Pegirian Surabaya dengan menggunakan media fotografi dapat dijadikan sebagai acuan untuk mendokumentasikan perubahan lingkungan yang terjadi, fotografi dapat digunakan sebagai alat agar anak dan masyarakat bisa berpartisipasi dalam kegiatan lingkungan ramah anak, dan dampaknya bagi keluarga yang diberikan tanaman urban farming mengalami perubahan perilaku menjadi lebih baik dalam merawat tanaman dan menjaga lingkungan serta hubungan antar anggota keluarga dan antar warga menjadi lebih erat.
\end{abstract}

Kata kunci: monitoring, urban farming, fotografi, partisipasi anak

\begin{abstract}
Photography as Monitoring Media on The Urban Farming Based on Documentation and Child Participation in Creating Children Friendly Environment in Pegirian Surabaya. This study discusses the problem of urban farming monitoring conducted by children by using photography learning media as a documentation of the environment where children live in the Surabaya area. The issues addressed discuss how the role of photography media is used as urban farming monitoring in Surabaya area and the impact of family and child monitoring with the participation of children in creating child friendly environment in Surabaya area. The method used is observation and interview. Data analysis activities started from the data collection stage, the reduction phase, the data presentation stage, and the conclusion with qualitative research. It can be concluded that the results of urban farming monitoring based on documentation and participation of children in creating child friendly environment in Pegirian area Surabaya by using photography media can be used as a reference to document the environmental change that happened, photography can be used as a tool so that children and society can participate in the activity child-friendly environment, and its impact on the family given the urban farming crop experienced better behavioral changes in caring for plants and maintaining the environment and relationships between family members and between citizens became more intimate.
\end{abstract}

Keywords: monitoring, urban farming, photography, child participation 


\section{PENDAHULUAN}

U-Health merupakan salah satu project Wahana Visi Indonesia yang berada di Kelurahan Pegirian, Kecamatan Semampir Surabaya. Proyek ini berawal dari proyek U-Star (Urban Surabaya Transformation and Research) pada tahun 2009 yang bertujuan untuk menginisiasi dan menjaring suara anak untuk membantu mewujudkan Kampung Ramah Anak (KRA) di Kelurahan Pegirian dan Surabaya Kota Layak Anak (SKLA). Dari pendampingan ini, anak-anak melalui kelompok anak menyebutkan setidaknya ada 7 indikator utama yang mereka ingin ubah agar dapat menciptakan KRA di Pegirian, yang salah satu indikatornya adalah Mewujudkan Kampung yang Bersih dan Sehat.

Urban farming dijadikan salah satu pendekatan strategi yang digunakan Wahana Visi Indonesia (WVI) untuk mewujudkan lingkungan yang bersih dan hijau untuk kepentingan terbaik bagi anak sebagai salah satu indikator dari perwujudan Kampung Ramah Anak di Wilayah Kelurahan Pegirian, Surabaya. Urban farming merupakan upaya pemberdayaan masyarakat melalui gerakan penghijauan dan sekaligus memberikan keuntungan ekonomi bagi masyarakat di wilayah dampingan, biasa dikenal dengan istilah ekonomi hijau (ecogreen). Tanaman sayuran misalnya, dapat dimanfaatkan untuk memenuhi kebutuhan makanan keluarga sehingga mengurangi pengeluaran keluarga. Hal ini tentunya merupakan keuntungan ekonomis bagi masyarakat.

Untuk pelaksanaan urban farming ini, WVI dibantu oleh Universitas Pembangunan Nasional (UPN), Fakultas Pertanian dalam hal penyediaan tanaman dan pendampingan secara teknis. Universitas Pembangunan Nasional dipandang sebagai pihak yang memiliki keunggulan dalam hal pengetahuan secara teori dan praktik mengenai pemilihan dan perawatan tanaman yang cocok untuk ditanam di wilayah Pegirian dengan karakter yang panas, berdebu, dan kering. Pendampingan ini dilakukan sejak awal tahun 2014 hingga sekitar April 2015 dengan didahului kegiatan baseline untuk mengukur data awal mengenai apa saja yang diperlukan oleh masyarakat terkait urban farming. Di Kelurahan Pegirian dipilih 4 RW sebagai wilayah percontohan pengembangan Ecogreen ini, yaitu RW 07, 08, 09 dan 10.

Aktivitas dimulai dengan melakukan sosialisasi program yang melibatkan perwakilan RW, RT, dan PKK. Dalam sosialisasi disampaikan tujuan program dan komitmen dari pengurus masyarakat dalam memelihara tanaman yang akan didistribusikan berdasarkan hasil assessment, untuk itu dipilih penanggung jawab di masing-masing wilayah. Aktivitas berlanjut dengan kerja bakti masal di bawah komando pengurus RW, dengan tujuan untuk melibatkan peran serta masyarakat. Ketika dilakukan distribusi tanaman, masyarakat diberikan pelatihan pencampuran dan pembuatan media tanam (tanah dan kompos). Sampai akhir tahun 2014, WVI dan UPN sudah melakukan pendampingan dan pemberian tanaman kepada 435 KK di 4 RW di Kelurahan Pegirian. Jenis tanaman yang diberikan berupasayuran, buah-buahan, obat-obatan, dan tanaman hias. Pihak Universitas juga mengajarkan beberapa teknologi hijau yang dapat diterapkan di masyarakat, seperti teknologi vertikultur untuk pembibitan dan penanaman sayur dan pengolahan sampah basah menjadi kompos.

Untuk monitoringnya sendiri dilakukan bersamaan dengan pembagian 
tanaman dari UPN. Hal ini dikarenakan oleh bentuk monitoringnya yang dilakukan oleh anak-anak untuk memberikan pantauan tentang tanaman yang diberikan, bagaimana pertumbuhan tanamannya, dan mewawancarai penerima tanaman agar mengetahui dampak dan pengaruh yang terjadi kepada anak, keluaga, dan masyarakat setelah diberikan tanaman urban farming.

Penulis sebagai fasilitator ingin memberikan gambaran tentang monitoring lingkungan yang dilakukan oleh anak yang berisi foto hasil pantauan yang dihasilkan oleh anak. Hal ini juga sebagai bentuk monitoring anak kepada masyarakat untuk mewujudkan keinginan mereka menjadikan lingkungan yang bersih dan hijau, serta dampak bagi keluarga dan anak yang telah mendapatkan tanaman urban farming pada lingkungan mereka.

Penelitian bertujuan untuk mendapatkan data tentang monitoring urban farming berbasis pendokumentasian dan partisipasi anak dalam menciptakan lingkungan ramah anak di wilayah Pegirian Surabaya. Metode yang digunakan adalah kualitatif-deskriptif. Metode kualitatif digunakan untuk mendapatkan data yang mendalam, suatu data yang mengandung makna. Makna adalah data yang sebenarnya, data yang pasti dan merupakan suatu nilai di balik data yang tampak (Afiffudin dan Saebani, 2012: 59). Makna yang berusaha untuk ditunjukkan pada penelitian ini mengetahui peran media fotografi digunakan sebagai monitoring urban farming di wilayah Pegirian Surabaya serta dampak monitoring keluarga dan anak dengan partisipasi anak dalam menciptakan lingkungan ramah anak di wilayah Pegirian Surabaya. Jenis penelitian yang digunakan adalah deskriptif, yakni untuk mendeskripsikan teori belajar humanisme yang dilakukan anak ketika monitoring urban farming dilakukan.

\section{PEMBaHASAN}

\section{Fotografi Sebagai Media Pembelajaran Monitoring Anak di Wilayah Pegirian Surabaya}

Monitoring, evaluasi, dan pembelajaran merupakan bagian dari siklus program pemberdayaan masyarakat, untuk melihat perkembangan dan dampak dari perencanaan dan pelaksanaan suatu program

Monitoring yang memberdayakan adalah monitoring yang berbasis partisipasi dan dokumentasi, agar kelak di kemudian hari dapat digunakan sebagai rekam jejak perubahan sosial dalam kaitan dengan evaluasi dan pembelajaran.

Monitoringberbasis pedokumentasian menggunakan foto sebagai alat monitoring. Foto sebagai salah satu media dokumentasi telah digunakan sebagai media monitoring dan media pembelajaran dalam programprogram pemberdayaan. Keunggulan foto sebagai media monitoring adalah kegiatannya bisa dilakukan secara individual dan kolektif, dimana kegiatan ini akan berkontribusi pada program pemberdayaan itu sendiri. Selain dapat dilakukan secara individual atau kolektif, foto memiliki kekuatan sebagai penyampai pesan secara visual yang lebih mudah dimengerti oleh semua kalangan. Foto dapat berbicara sebelum dan sesudah kegiatan pemberdayaan dilakukan.

Monitoring partisipatif dengan menggunakan foto dilakukan oleh anakanak yang melaksanakan program dan menikmati manfaat program. Untuk meningkatkan kapasitas pelaku monitoring dengan menggunakan foto perlu dilakukan pelatihan singkat tentang metode teknik fotografi dan metode penyajian monitoring sesuai dengan prinsip jurnalistik dasar. 


\section{Tujuan Pendokumentasian}

Tujuan kegiatan pemantauan urban farming adalah:

1. foto untuk pendokumentasian perubahan lingkungan secara berkala;

2. foto sebagai alat agar masyarakat dapat berpartisipasi dalam kegiatan;

3. foto sebagai media pembelajaran komunitas;

4. foto sebagai pelengkap pengetahuan dan kecakapan teknologi fotografi anak-anak, remaja dan kaum muda khususnya di Surabaya untuk memasuki era Teensyouth and Technology.

\section{Hasil yang diharapkan}

Harapan terhadap hasil kegiatan pemantauan urban farming ini yakni:

1. anak-anak dan remaja dapat mendokumentasikan perkembangan kegiatan urban farming;

2. anak-anak dan remaja dapat mengerti bahwa foto dapat dijadikan media pembelajaran baik secara individual maupun berkelompok;

3. adanya album foto yang bercerita tentang masyarakat yang melakukan penghijauan;

4. penggunaan foto untuk catatan diskusi perkembangan lingkungan dan perencanaan di masa mendatang;

5. anak-anak memiliki prestasi dan rasa bangga dari penyelenggaraan lomba penghijauan lingkungan.

\section{Peran Fotografi Digunakan Sebagai Monitoring Urban Farming di Wilayah Pegirian Surabaya}

Proses belajar mengajar seringkali dihadapkan pada materi yang abstrak dan diluar pengalaman siswa atau anak sehari-hari, sehingga materi menjadi sulit diajarkan oleh guru atau fasilitator dan sulit dipahami oleh siswa. Visualisasi adalah salah satu cara yang dapat dilakukan untuk mengkonkritkan sesuatu yang abstrak. Tidak bisa dipungkiri bahwa teknologi saat ini telah membawa kita ke arah era digitalisasi dan salah satunya adalah fotografi mampu memberi kesan yang besar dalam bidang media pembelajaran.

Fotografi adalah proses membuat gambar, yaitu menangkap cahaya dengan film. Pola cahaya yang dipantulkan atau dikeluarkan obyek direkam oleh medium atau chip melalui waktu ekspose tertentu/ proses ini dilakukan melalui proses mekanis, kimia atau perangkat digital yang kita kenal sebagai kamera. Fotografi telah lama menjadi bagian dari kehidupan kita sebagai manusia. Bersama dengan keluarga dan segala proses kehidupan, fotografi merupakan pendokumentasian paling nyata yang bisa berbicara.

Gambar fotografi pada dasarnya dapat membantu mendorong para anak dan dapat membangkitkan minatnya pada saat kegiatan monitoring. Membantu anakanak dalam mengembangkan kemampuan berbahasa, kegiatan seni dan pernyataan kreatif dalam bercerita, dramatisasi serta membantu anak untuk mengingat isi materi bacaan dari buku teks. Demikian pula pemahaman pengertian mengenai kemasyarakatan bisa diperoleh dari gambar fotografi, dan dalam situasi tertentu gambar fotografi merupakan sumber terbaik untuk tujuan atau penyelidikan penelitian.

Sebelum anak-anak melakukan monitoring urban farming dilakukan pelatihan fotografi tentang fotografi dasar yang berisi tentang sejarah fotografi, komposisi, serta tata cahaya terlebih dahulu agar mereka tahu tentang ilmu fotografi dan pengambilan gambar yang baik, memegang kamera yang baik dan dapat mengerti tentang kamera yang mereka pakai. Setelah anak -anak mengetahui 
tentang cara memotret yang baik, anakanak diberikan arahan dan pemahaman agar dapat membuat foto bercerita untuk menggambarkan kegiatan urban farming.

Monitoring

berbasis

pedokumentasian menggunakan foto sebagai alat monitoring. Fotografi sebagai salah satu media dokumentasi telah digunakan sebagai media monitoring dan media pembelajaran dalam programprogram pemberdayaan. Fotografi memiliki keunggulan dalam menceritakan proses monitoring, sebelum diberikan tanaman urban farming hingga setelah tanaman tersebut tumbuh subur.

Komunitas anak yang ada di Pegirian mengikuti pelatihan dan monitoring lingkungan dengan senang dan antusias. Kepedulian mereka terhadap keadaan sekitar tercermin dari bagaimana mereka melihat, mengamati, mewawancarai dan memotret.

Paling tidak terdapat 4 (empat) tujuan dari riset aksi menurut Eileen Ferrance (2000), yaitu:

1. terjadinya pemberdayaan partisipan (subyek penelitian);

2. terjadinya kolaborasi bersama partisipan ;

3. terdapatnya perolehan pengetahuan baru;

4. terwujudnya perubahan sosial.

Monitoring dengan anak berusaha untuk menempatkan anak-anak di tengah proses monitoring dengan mendorong partisipasi anak-anak dalam sebagian besar tahapan. Dengan demikian, anakanak tidak hanya menjadi peserta, anakanak adalah mitra sejajar dalam riset. Hal ini sesuai dengan salah satu prinsip Konvensi Hak Anak (KHA) yakni hak untuk berpartisipasi (Pasal 12). Pasal ini menegaskan anak-anak berhak untuk bersuara dan suara anak-anak harus didengar terkait dengan situasi dan konteks yang mempengaruhi kehidupan anak.

Monitoring yang dilakukan anakanak adalah memotret dengan kamera poket digital Canon dan wawancara dengan narasumber atau penerima manfaat. Dengan pertanyaan yang sudah dirangkai mereka mulai bertanya tentang urban farming.

Kemandirian anak dalam melakukan pelatihan fotografi tidak terlepas dari rasa keingintahuan anak-anak dalam ilmu fotografi. Penulis selaku fasilitator dalam memberikan ilmu fotografi dasar yang berisi prinsip dasar fotografi, lalu untuk mengukur pencahayaan diperlukan eksposure yang tepat kombinasi antara kecepatan dan diafragma. Penulis menerangkan tentang sejarah fotografi dari awal terciptanya kamera hingga kamera digital muncul. Lalu penulis memberikan penjelasan mengenai jenis-jenis fotografi yang ada serta komposisi dan tata cahaya dalam pengambilan fotografi.

Penulis selaku fasilitator menggunakan teori belajar humanistik dengan gaya belajar Kolb di dalam pengajaran fotografi dan monitoring lingkungan. Teori belajar humanisik cenderung mengarahkan siswa untuk berpikir induktif, mementingkan pengalaman, serta membutuhkan keterlibatan anak secara aktif dalam proses belajar. Oleh sebab itu, walaupun secara eksplisit belum ada pedoman baku tentang langkah-langkah pembelajaran dengan pendekatan humanistik. 


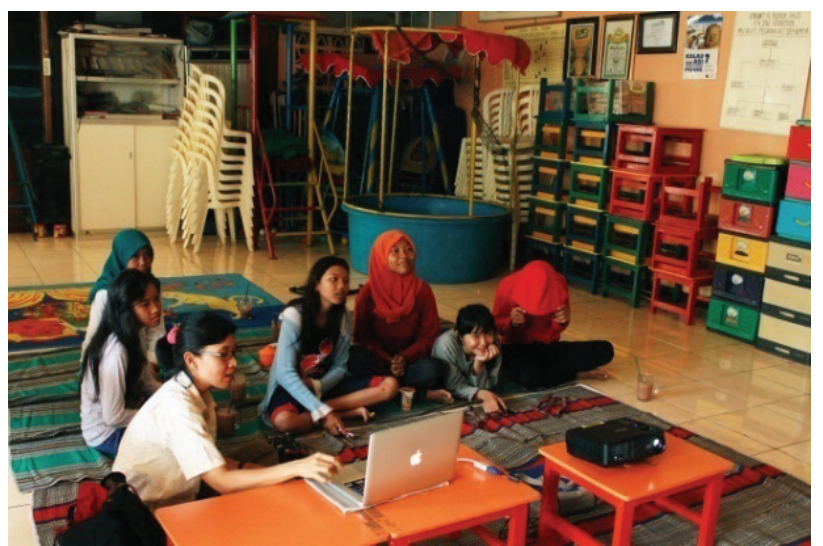

Gambar 1 .

Pelatihan fotografi tentang komposisi fotografi

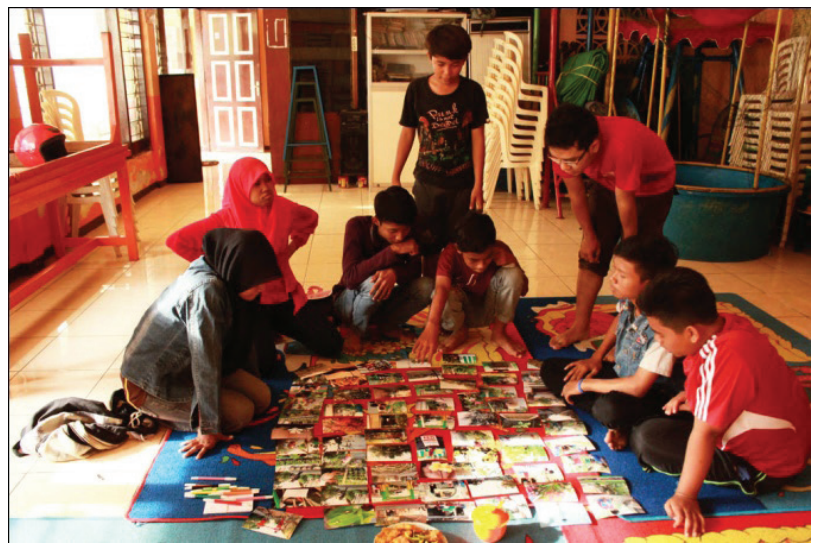

Gambar 2

Anak- anak memilih foto untuk dijadikan cerita

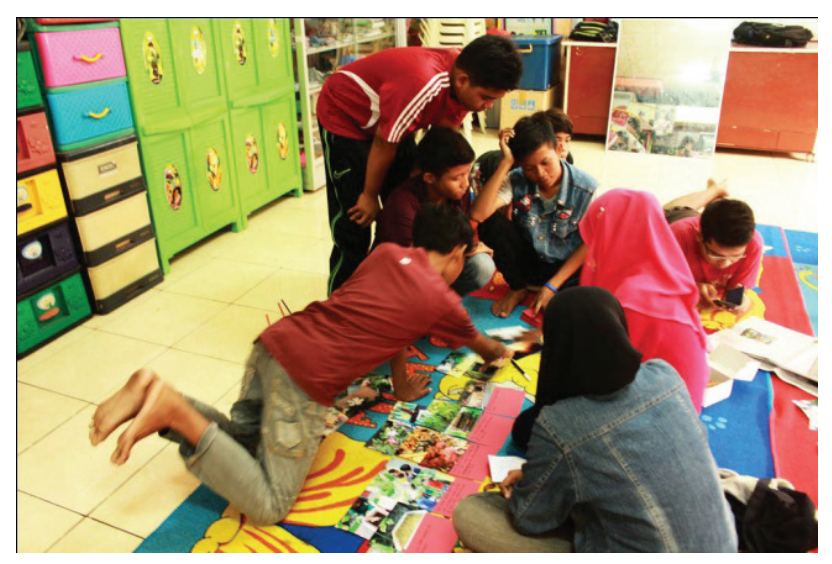

Gambar 3.

Mulai merangkai dan membuat alur pada foto bercerita

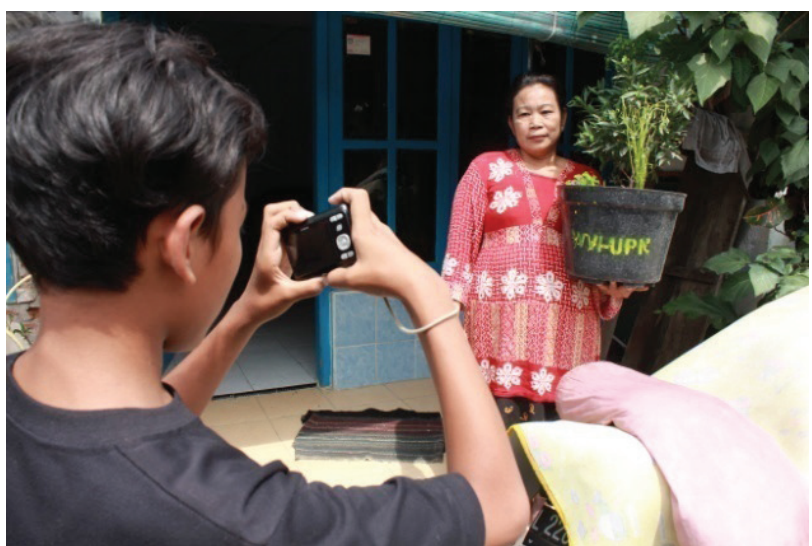

Gambar 4

Septiyan, salah satu peserta anak yang mengikuti monitoring tanaman urban farming memotret penerima tanaman pucuk merah

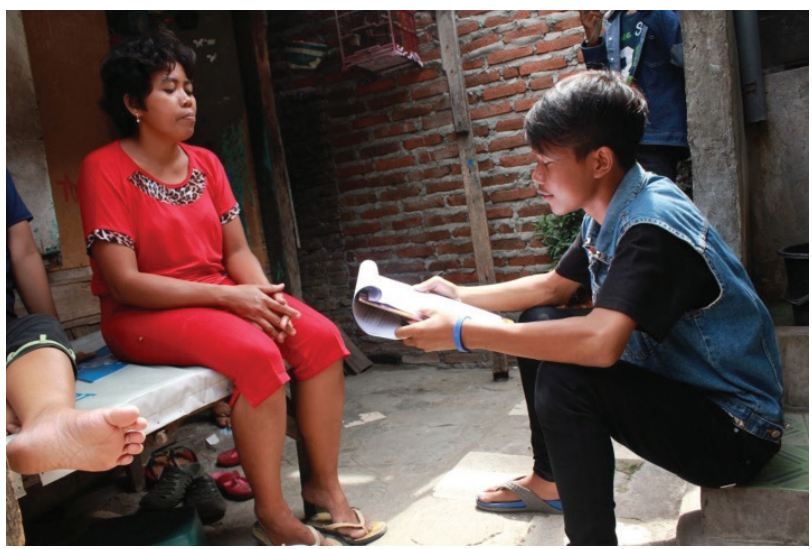

Gambar 5.

Bramastya, salah satu anak yang mewawancarai Ibu Tian penerima tanaman pucuk merah di RW 08

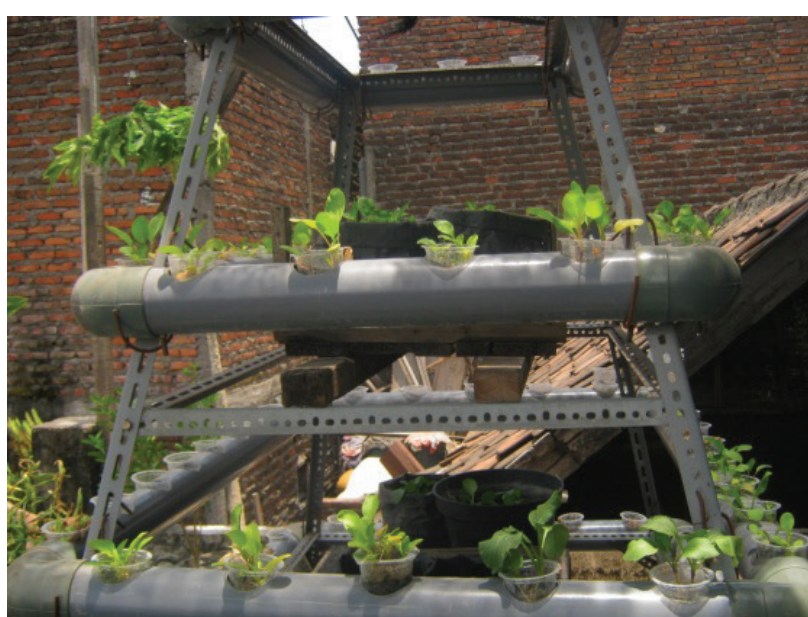

Gambar 6.

Salah satu tanaman urban farming yang ada di RW 08 
Dalam teori ini, anak berperan sebagai pelaku utama (student center) yang memaknai proses pengalaman belajarnya sendiri. Ketika anak memahami potensi diri, diharapkan anak dapat mengembangkan potensi dirinya secara positif dan meminimalkan potensi diri yang negatif. Menurut Kolb, experiental learning adalah suatu proses dimana pengetahuan hasil dari kombinasi yang berbeda dari menangkap dan menransformasikan pengalaman.

Gaya belajar Kolb ialah gaya belajar yang melibatkan pengalaman baru siswa, mengembangkan observasi/ merefleksi, menciptakan konsep, dan menggunakan teori untuk memecahkan masalah.

Menurut penulis, gaya belajar Kolb ini akan menjadi lebih sempurna bila dikaitkan dengan karakteristik gaya dan cara belajar siswa yang dikenal dengan tipe visual, auditory dan kinestetik.

Manusia visual menerima dan memproses informasi dengan cara melihat dan menciptakan gambaran mentalnya. Secara khas, orang visual akan menggunakan kata-kata seperti "tunjukkan kepada saya" atau "perlihatkan kepada saya” (Ramly, 2008: 41).

Manusia auditory menerima dan memproses informasi dengan mendengarkan kata-kata atau suara-suara. Orang auditory cenderung menggunakan kata-kata seperti "ceritakan kepada saya" (Ramly, 2008: 41).

Manusia kinestetik menerima dan memproses informasi melalui perasaan dan sensasi. Biasanya cepat berkata "rasanya seperti...” (Ramly, 2008: 41).

Kolb membagi belajar menjadi 4 tahap.

1. Tahap pengalaman konkrit (Concrete Experience) merupakan tahap awal, yakni seseorang mengalami suatu peristiwa sebagaimana adanya (hanya merasakan, melihat, dan menceritakan kembali peristiwa tersebut).

2. Tahap Pengalaman Aktif dan Reflektif (Reflection Observation). Pada tahap ini sudah ada observasi terhadap peristiwa yang dialami, mencari jawaban, melaksanakan refleksi, mengembangkan pertanyaanpertanyaan bagaimana peristiwa terjadi dan mengapa terjadi.

3. Tahap Konseptualisasi (Abstract Conseptualization). Pada tahap ini seseorang sudah berupaya membuat sebuah abstraksi, mengembangkan suatu teori, prosedur tentang sesuatu yang sedang menjadi objek perhatian.

4. Tahap Eksperimentasi Aktif (Active Experimental). Pada tahap ini sudah ada upaya melakukan eksperimen secara aktif, dan mampu mengaplikasikan konsep, teori ke situasi nyata.

Kelebihan pada gaya belajar humanisme Kolb ini sangat cocok untuk materi pembelajaran yang bersifat pembentukan kepribadian, hati nurani, perubahan sikap, dan analisis terhadap fenomena sosial. Siswa merasa senang bergairah, berinisiatif dalam belajar dan terjadi perubahan pola pikir, perilaku dan sikap akan kemauan sendiri, dan siswa menjadi pribadi yang bebas, berani dan tidak terikat oleh pendapat orang lain dan mengatur pribadinya sendiri secara bertanggung jawab tanpa mengurangi hak-hak orang lain atau melanggar aturan, norma, atau etika yang berlaku.

Kekurangan pada gaya belajar humanisme Kolb kurang cocok diterapkan pada siswa atau anak yang memiliki 
pola pikir yang kurang aktif atau pasif, siswa berperan sebagai student center maka keberhasilan proses belajar lebih banyak ditentukan oleh siswa itu sendiri; peran guru atau fasilitator dalam proses pembentukan dan pendewasaan kepribadian siswa menjadi berkurang.

Dari pelaksanaan rangkaian kegiatan monitoring urban farming dengan mengajak anak-anak untuk berpartisipasi dalam pendokumentasian diperoleh pembelajaran sebagai berikut.

1. Kegiatan yang melibatkan anakanak sebagai pelaku utama perlu memperhatikan kalender pendidikan (kegiatan anak di sekolah).

2. Sejumlah 13 orang anak, terdiri atas 6 orang anak laki-laki dan 7 anak perempuan memiliki pengetahuan dan keterampilan dalam fotografi dan pemantauan melalui wawancara.

3. Anak-anak tersebut melakukan hak anak, yaitu hak anak untuk berpartisipasi.

4. Sejumlah 13 orang anak yang telah memiliki keterampilan fotografi dan pemantauan, mampu melakukan pemantauan pertumbuhan tanaman dan perubahan perilaku warga di RW 07-RW 10.

5. Hasil pemotretan 13 orang anak tersebut menunjukan perkembangan dalam menggunakan kamera dan mengetahui teknik dasar fotografi; antara lain bagaimana melakukan pengaturan cahaya, pemilihan sudut, dan penentuan fokus. Hasil foto anak-anak sudah cukup baik untuk digunakan sebagai dokumen pemantauan.

6. Anak-anak memiliki potensi besar untuk diberdayakan dalam pembangunan lingkungan tempat tinggal anak. Hal ini terbukti dari hasil foto anak-anak yang dapat menceritakan proses pertumbuhan tanaman juga aktivitas warga dalam proses perawatannya.

7. Bahwa program monitoring urban farming berbasis pendokumentasian dan partisipasi anak dalam menciptakan lingkungan ramah anak di wilayah Surabaya dapat diterapkan di berbagai area urban untuk penghijauan lingkungan sekaligus pendidikan dan pemenuhan hak anak.

\section{Dampak Monitoring Keluarga dan Anak dengan Partisipasi Anak dalam Menciptakan Lingkungan Ramah Anak di Wilayah Pegirian Surabaya}

Dampak pelaksanaan rangkaian kegiatan monitoring berbasis pendokumentasian dan partisipasi anak adalah sebagai berikut:

1. Pemantauan dan pendokumentasian yang dilakukan di 4 RW (RW 7, RW 8, RW 9, dan RW 10) melibatkan 113 orang warga terdiri atas 86 orang perempuan dan 27 laki-laki. Keterlibatan 102 orang warga dalam pemantauan antara lain dalam bentuk menyampaikan pengalamannya ketika terlibat dalam urban farming, menyampaikan bagaimana perubahan situasi lingkungan, perubahan perilaku dan hubungan antaranggota keluarga dan antarmasyarakat menjadi lebih erat.

2. Lingkungan Pegirian tempat tinggal anak dan keluarga menjadi lebih hijau dan lebih ramah untuk anak karena dengan adanya tanaman tersebut, anak-anak dapat mempererat hubungan kasih sayang kepada orangtua serta masyarakat sekitarnya. 
3. Sebagian besar penerima tanaman program urban farming menyatakan bahwa program tersebut sangat bermanfaat dan masyarakat menginginkan penambahan jenis tanaman yang lebih banyak lagi, terutama jenis tanaman yang dapat menghasilkan buah.

4. Anak-anak yang mengikuti program pemantauan urban farming dengan menggunakan metode pendokumentasian telah berhasil menjadi agen perubahan lingkungan bagi tempat tinggalnya. Hal ini dikarenakan oleh adanya tanaman tersebut, hubungan orangtua dan anak yang tadinya tidak sering bicara karena kesibukan masingmasing, menjadi lebih akrab di saat menyirami atau memberi pupuk.

5. Dari hasil wawancara yang dilakukan oleh fasilitator, terdapat 4 orang siswa PAUD di RW 10 yang menjadi lebih menyukai tanaman, suka makan sayuran, dan menyukai pengetahuan tentang proses penanaman sayur. Untuk program urban farming di PAUD, diberikan bibit tanaman sayur bayam hijau dan bayam merah.

6. Hasil wawancara dengan sebagian besar perempuan dewasa yang diberikan tanaman urban farming menegaskan dengan adanya tanaman urban farming, ketika sayurannya sudah memasuki masa panen, dapat dipetik dan dimasak sendiri atau dijual kembali. Hal ini membuat para ibu tersebut memiliki penghasilan sendiri dan dapat memasak sayur sehat untuk keluarganya.

\section{SIMPULAN}

Kesimpulan dari pelaksanaan rangkaian kegiatan monitoring urban farming dengan mengajak anak-anak untuk berpartisipasi dalam pendokumentasian diperoleh pembelajaran sebagai berikut: fotografi dapat menjadi alat pemberdayaan dalam monitoring karena fotografi sebagai salah satu media dokumentasi telah digunakan sebagai media monitoring dan media pembelajaran dalam programprogram pemberdayaan. Fotografi memiliki keunggulan dalam menceritakan proses monitoring, sebelum diberikan tanaman urban farming hingga setelah tanaman tersebut tumbuh subur.

Hasil pemotretan ke 13 orang anak tersebut menunjukkan perkembangan kemampuan dalam menggunakan kamera dan memotret. Anak-anak sudah dapat menggunakan kamera dalam hal sudut pengambilan gambar yang baik, pengaturan cahaya, dan penentuan fokus. Foto-foto tersebut sudah cukup baik untuk digunakan sebagai dokumen pemantauan.

Sejumlah 13 orang anak, terdiri atas perempuan memiliki pengetahuan dan keterampilan dalam fotografi dan pemantauan melalui wawancara. Dengan demikian program pemantauan dapat digunakan sebagai salah satu strategi untuk memenuhi dan melaksanakan hak partisipatif anak.

Pemantauan dan pendokumentasian yang dilakukan di 4 RW (RW 7, RW 8, RW 9, dan RW 10) melibatkan 113 orang warga terdiri dari 86 orang perempuan dan 27 laki-laki. Keterlibatan 102 orang warga dalam pemantauan antara lain dalam bentuk menyampaikan pengalamannya ketika terlibat dalam Urban Farming, menyampaikan bagaimana perubahan situasi lingkungan, perubahan perilaku dan hubungan antar anggota keluarga dan antar masyarakat menjadi lebih erat.

Anak-anak memiliki potensi besar untuk diberdayakan dalam pembangunan 
lingkungan mereka. Hal ini terbukti dari hasil foto anak-anak yang dapat menceritakan proses pertumbuhan tanaman juga aktivitas warga dalam proses perawatannya. Selain itu anakanak dituntut untuk dapat berpikir kritis dan terbuka ketika melakukan program monitoring urban farming di Pegirian Surabaya. Dengan memberikan alat berupa kamera kepada anak-anak untuk menceritakan kegiatan pemantauan, Wahana Visi Indonesia telah memberikan apresiasi, kesempatan, dan tantangan bagi komunitas anak tersebut untuk dapat ikut berperan menceritakan perubahan lingkungan yang signifikan.

\section{Ucapan Terima Kasih}

Dengan adanya pemantauan urban farming ini, telah diberikan pembelajaran berupa perubahan masyarakat di area program Kelurahan Pegirian; antara lain yaitu mengubah perilaku hubungan orangtua dan anak-anak menjadi lebih erat.

Terimakasih atas kepercayaan Wahana Visi Indonesia Surabaya yang telah memberikan kesempatan kepada penulis untuk melakukan penelitian dalam pemantauan urban farming di RW 07, RW 08, RW 09, dan RW 10 di Kelurahan Pegirian.

Terimakasih tak terhingga kepada para narasumber yaitu masyarakat Pegirian di RW 07, RW 08, RW 09, dan RW 10; serta anak-anak yang mengikuti program pemantauan urban farming berbasis pendokumentasian dan partisipasi anak di Pegirian Surabaya.

\section{KEPUSTAKAAN}

Saebani, Beni Ahmad dan Afifuddin. (2012) Metodologi Penelitian Kualitatif. Bandung: CV Pustaka Setia.

Mrazkova,Daniela. (1988). Master of Photography: A Thematic History. Chicago: Bookthrift.

Daryanto. (2013). Media Pembelajaran Peranannya Sangat Penting Dalam Mencapai Tujuan Pembelajaran. Yogyakarta: Gava Media.

Ferrance, Eileen. (2000). Action Research. Rhode Island: Brown University.

Siregar, Eveline. (2010). Teori Belajar dan Pembelajaran. Jakarta: Ghalia Indonesia.

Vivian, J. (2008). Teori Komunikasi Massa. Jakarta: Kencana. 